\title{
Expanding diagnostic approach in patients with osteonecrosis
}

\author{
José A. Gómez-Puerta (iD and Pilar Peris
}

To the editor,

We read with interest the manuscript recently published by Yokota and colleagues [1]. Whole-body MRI (WB-MRI) is an attractive tool for the diagnosis of patients with high risk of developing multifocal osteonecrosis $(\mathrm{ON})$. In many cases, concordance between symptoms and diagnostic images is poor; therefore, as suggested by the authors, high suspicion is needed. Compared with whole-body bone scintigraphy (WB-BS), in this study, a significant proportion of patients with asymptomatic ON were identified using WB-MRI (being the knees and the shoulders the most frequent underdiagnosed affected locations), thereby indicating that this method should be used for a more correct diagnostic and therapeutic approach.

Treatment of patients with ON, especially those with multifocal ON, remains a great challenge for clinicians. Although the authors indicated the need to better identify the patients at risk for this extensive type of $\mathrm{ON}$, they did not mention any additional study related to the presence of associated coagulation abnormalities, which are a relatively common finding as described previously by our group and others in patients with multifocal ON $[2,3]$. Indeed, in a previous observational study in a series of 29 patients with multifocal ON [2], we observed the presence of coagulation abnormalities in nearly $50 \%$ of the patients after performing a wide thrombophilic profile panel. Of note, most of the patients (65\%) also had a present or previous history of glucocorticoid treatment indicating the importance of both glucorticoid treatment and coagulation abnormalities as associated risk factors. In our study, the most common prothrombotic alterations were high factor VIII levels and the presence of antiphospholipid antibody.

\footnotetext{
* Correspondence: jagomez@clinic.cat
}

Rheumatology Department, Hospital Clinic de Barcelona, Villarroel 170, 08036 Barcelona, Spain

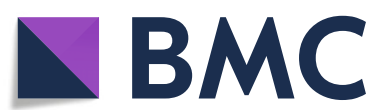

(c) The Author(s). 2021 Open Access This article is licensed under a Creative Commons Attribution 4.0 International License, which permits use, sharing, adaptation, distribution and reproduction in any medium or format, as long as you give appropriate credit to the original author(s) and the source, provide a link to the Creative Commons licence, and indicate if changes were made. The images or other third party material in this article are included in the article's Creative Commons licence, unless indicated otherwise in a credit line to the material. If material is not included in the article's Creative Commons licence and your intended use is not permitted by statutory regulation or exceeds the permitted use, you will need to obtain permission directly from the copyright holder. To view a copy of this licence, visit http://creativecommons.org/licenses/by/4.0/ The Creative Commons Public Domain Dedication waiver (http://creativecommons.org/publicdomain/zero/1.0/) applies to the data made available in this article, unless otherwise stated in a credit line to the data.
Also, of interest in relation to the Yokota study is the influence of the WB-MRI diagnosis on the clinical approach to these patients. Did the patients diagnosed with multifocal $\mathrm{ON}$ in the present study receive additional or differential treatment compared with those with oligarticular forms of $\mathrm{ON}-$ particularly when asymptomatic?

The present study provides a useful tool for diagnosing this clinical entity, which seems to be more frequent than previously indicated, with the use of a more sensitive test such as WB-MRI. Nevertheless, the identification of high-risk patients for this complication is essential. Therefore, in addition to the wider and more accurate and sensitive WB-MRI imaging approach, complementary tests of pro-thrombotic factors are recommended to better identify patients at high risk of multifocal ON who could be candidates for antiplatelet, antiaggregant, or even anticoagulant therapy, among others $[4,5]$.

\section{Authors' contributions \\ Both authors contributed in the preparation and final review of this manuscript. The authors read and approved the final manuscript.}

\begin{abstract}
Funding
No funding was needed for the current manuscript.
\end{abstract}

Availability of data and materials

Data from original article cited is available under request.

\section{Declarations \\ Ethics approval and consent to participate \\ The original article cited was approved by the local committee. \\ Consent for publication \\ We consent publication of our letter in Arthritis Research and Therapy.}

Competing interests

The authors declare that they have no competing interests. 
Received: 17 March 2021 Accepted: 18 May 2021

Published online: 25 May 2021

\section{References}

1. Yokota S, Sakamoto K, Shimizu Y, Asano T, Takahashi D, Kudo K, et al. Evaluation of whole-body modalities for diagnosis of multifocal osteonecrosis—a pilot study. Arthritis Res Ther. 2021;23(1):83 https://doi. org/10.1186/s13075-021-02473-3.

2. Gómez-Puerta JA, Peris P, Reverter JC, Espinosa G, Martinez-Ferrer A, Monegal $A$, et al. High prevalence of prothrombotic abnormalities in multifocal osteonecrosis: description of a series and review of the literature. Medicine (Baltimore). 2013;92(6):295-304. https://doi.org/10.1097/MD. 0000000000000007.

3. Glueck CJ, Freiberg RA, Boppana S, Wang P. Thrombophilia, hypofibrinolysis, the eNOS T-786C polymorphism, and multifocal osteonecrosis. J Bone Joint Surg Am. 2008;90(10):2220-9. https://doi.org/10.2106/JBJS.G.00616 PMID: 18829920.

4. Lespasio MJ, Sodhi N, Mont MA. Osteonecrosis of the hip: a primer. Perm J. 2019;23:18-100.

5. Glueck CJ, Freiberg RA, Wang P. Long-term anticoagulation prevents progression of stages I and II primary osteonecrosis of the hip in patients with familial thrombophilia. Orthopedics. 2020;43(4):e208-14. https://doi. org/10.3928/01477447-20200404-06.

\section{Publisher's Note}

Springer Nature remains neutral with regard to jurisdictional claims in published maps and institutional affiliations. 